\title{
SOCIO-GEOGRAPHIC CHARACTERISTICS OF THE ALBANIAN FAMILY DURING THE TRANSITION PERIOD (IN THE SOUTH OF ALBANIA)
}

DOI: http://dx.doi.org/10.18509/GBP.2015.52

UDC: 911.3/316.356.2(496.5-13)

\author{
Assoc. Prof. Dr. Valbona Duri \\ "E.Çabej" University, Gjirokaster, Albania
}

\begin{abstract}
The family, its evolution, has a direct impact on the reproductive potential of the population. For this reason its study is necessary.

Possibilities or impossibilities for employment, income levels, economical structure and the development, education level, the level of urbanization, gender and age composition of the population the birth rate, family planning, mortality general and specific, emigration, the force of tradition, etc., are the main factors have determined the sociogeographical characteristic features of Albanian society, during the transition political, economic and demographic period in Albania.

* The substitution of the centrally planned socialist economy with the free market.

$\boldsymbol{x}$ Economic crisis at the beginning of 1990.

$\boldsymbol{x}$ The increase of the unemployment.

$\boldsymbol{x}$ The reduction of income.

$\boldsymbol{x}$ The family planning policy.

$\boldsymbol{x}$ The flow of rural population to the cities.

$\boldsymbol{x}$ The abandonment of the villages.

$\boldsymbol{*}$ The emigration,

$\boldsymbol{x}$ The aging demographic

$\boldsymbol{x}$ The change of gender ratio (because of male emigration).

x The traditional psychology,

$\boldsymbol{*}$ The economic insecurity.
\end{abstract}

These are the main factors that brought evident change in the Albanian family performance and characteristics, marriage, divorce rate and civil structure of the population too, in the south of Albania. This region is distinguished for a clear profile emigration, because of the positioning of the neighboring country, Greece, and the presence of the Greek minority.

Decrease or reduction of the total number of the families, marriages too, after 1990 in this area, has been analyzed under the influence of economical changes, which have an important impact on the creation of new families. Meanwhile, the index of divorce rate per 1000 inhabitants is increased, compared with 1989.

\section{INTRODUCTION}

During and after 1990, some political, economic and social changes occurred which greatly influenced the demographic developments in Albania. Migration is one of the most determining factors which brought those changes closely into every Albanian family during this economic transition. Albanian families came from a large unit of two or more pairs (crowns in English), and many family members, while now it is replaced by smaller families (parents) with only two children per family. From 7 children in 1950, down to 5 children in1970, followed by 4 children in1980, and down again to 3 children in 1990. 
The impact of immigration in the country, mostly affecting the young generation followed by a low birth rate (from $31.1 \%$ to $7.0 \% 1960$ (2011), was reinforced by a decline in marriage rates. Another factor to be mentioned was a high increase in divorce rates which contributed greatly to those factors. In comparison to other European countries, the fertility decline came late, but this process was conducted with the highest intensity. This phenomenon is very striking, especially when it comes to a large family unit, reduced to only three family members (two parents plus a child).

\section{THE FAMILY DYNAMICS, THE NUMBER OF HOUSEHOLDS AND ITS STRUCTURE AFTER 1990.}

The family, with a concrete number structure and its evolution in time and space, has a direct impact on the reproductive potential of the population. In this regard its study constitutes a necessity.

The developing of numerical structure family, it's been seen as a process with a number of factors such as demographic, economic, social, psychological, tradition etc.

Studimi i dinamikës së numrit të familjeve ne jug te Shqiperise, tregon se ky numër është rritur $17.8 \%$, kundrejt vitit 1989. Pas ketij viti(1989), ne Shqiperi ndodhin ndryshime te rendesishme ne sistemin politik, ekonomik etj. Sistemi socialist zevendesohet nga ekonomia e lire e tregut, pronesia shteterore nga ajo private, politika pronataliste nga planifikimi familjar, rifillon emigrimi i jashtem, etj.

The study in the dynamics of the number of families in southern Albania shows that this number has increased by up to $17.8 \%$, compared to 1989. After that year (1989), important political and economical changes took place. The socialist system is replaced by a free market economy; state ownership replaced by private ownership, followed by family planning policies, migration etc.

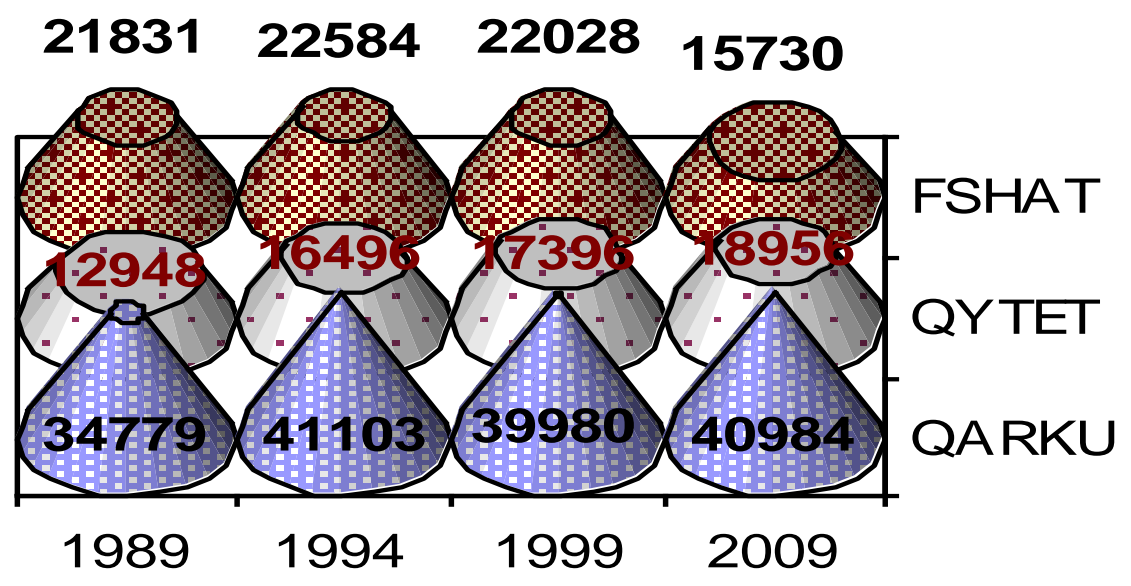

Figure Nr 1. The number of households in Gjirokastra region[5] [3 ] The graphic prepared by V.Duri

Dynamics (performance) of the number of households fails to give a complete picture of the changes that have taken place within it. For this purpose, we have to analyze only the dynamics of the average number per family member. According to settlements (urbanrural), this indicator is higher (4.4 members / family) in the village and a low of 3.7 members families in the city. The reason lies in the greater fertility of the rural population 
which is motivated or conditioned by the demand for labor that has no mechanized agriculture.

Table Nr. 1 The number of households in Gjirokastra region [5] [3 ]

(population /families= average member/families), Accrued by V. Duri

\begin{tabular}{|c|c|c|c|c|c|}
\hline \multirow[b]{2}{*}{ Units } & 1989 & 1994 & 1999 & 2009 & \multirow{2}{*}{$\begin{array}{c}\text { Change } \\
\text { the average nr } \\
\text { Members / } \\
\text { Family(''89-'09) }\end{array}$} \\
\hline & $\begin{array}{c}\text { Average } \\
\text { members/family }\end{array}$ & $\begin{array}{l}\text { Average } \\
\text { members/family }\end{array}$ & $\begin{array}{l}\text { Average } \\
\text { members } \\
\text { /family }\end{array}$ & $\begin{array}{l}\text { Average } \\
\text { members } \\
\text { /family }\end{array}$ & \\
\hline District & 4.6 & 4.0 & 4.3 & 4.1 & -20.4 \\
\hline Urban area & 4.2 & 3.6 & 4.0 & 3.7 & -7.8 \\
\hline Rural area & 4.9 & 4.2 & 4.5 & 4.4 & -27.9 \\
\hline
\end{tabular}

Statistics conclude that increasing numbers of families into the area in the study has been slow. This situation has come about as a consequence of the change (fall) in the number of marriages, increase the number of divorces, declining fertility, mobility (migration) of the population, etc.

\section{NUMERICAL EVOLUTION OF FAMILIES IN SPATIAL (LAND) DISTRIBUTION}

In spatial terms, the number of households in the city represents an increase by $46.4 \%$, while the village has decreased by $27.9 \%$ compared to 1989 .

The apparent reduction in the number of families in the village is explained by a greater involvement of this population in the migration to the city, outside the county and abroad. The phenomenon of family contraction has been greatly noticed mostly in villages where due to migration factors the number of families in the village has drastically decreased, in comparison to the city. In the countryside, the decrease in the average number of family members resulting from 4.9 members (1989) to 4.4 members (2011), while in the city this indicator has decreased from 4.2 to 3.7 members / family.

Change in size of the family is made in two steps. The first step is the reduction of large families into small ones followed later by a reduction in having new born children as a result of a lower fertility rate. These changes are related to numerous factors such as social and economic, as well the rising of urbanization level in the county (rate urbanization), migration of the population outside the county, increasing the educational level of women etc.

The dynamics of the number of families in the territory under this study, presents differences according to the districts.

After 1989, the total number of households has fallen in the three districts of the county. According to the level of reduction, the first place is Tepelenë district (-27.2\%), Përmeti($26.2 \%$ ) and finally Gjirokastra(-12.3\%), versus 1989. 


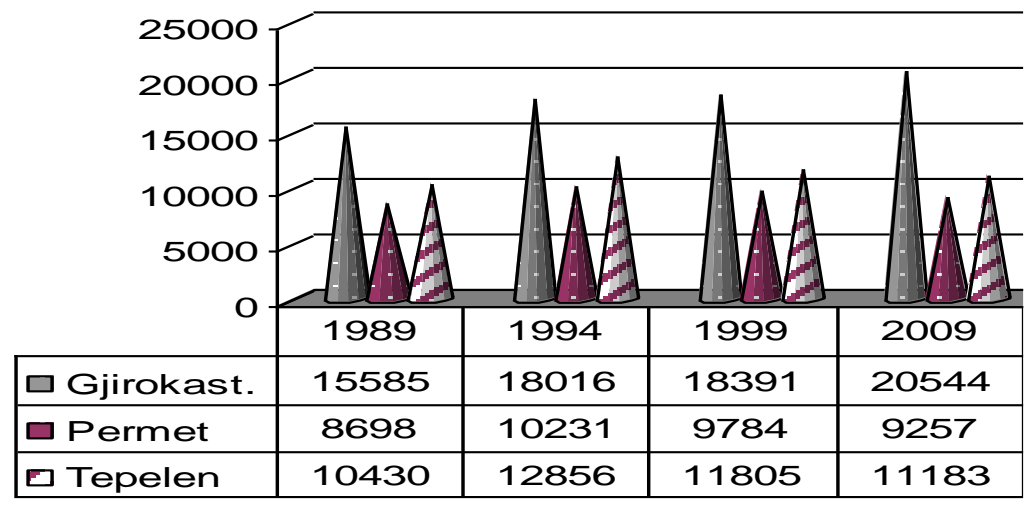

Figure Nr.2. The number of households in Gjirokastra region by districts. [5 ], [3] The graphic prepared by V.Duri

The decrease in the average number of members / families also appear high in the district Tepelenë, the members dropped from 4.9 to 3.9 members. The district of Permet from 4.6 to 4.2 members and Gjirokastra from 4.4 to 4.0 members / family.

Table Nr.2. Number of households in Gjirokastra district by district [5 ] [3] (population / families= average member/families), Accrued by V. Duri

\begin{tabular}{|l|c|c|c|c|c|c|}
\hline \multirow{2}{*}{ Units } & 1989 & 1994 & 1999 & 2001 & 2009 & The change \\
\cline { 2 - 7 } & $\begin{array}{c}\text { Average } \\
\text { members / } \\
\text { family }\end{array}$ & $\begin{array}{c}\text { Average } \\
\text { members / } \\
\text { family }\end{array}$ & $\begin{array}{c}\text { Average } \\
\text { members / } \\
\text { family }\end{array}$ & $\begin{array}{c}\text { Average } \\
\text { members / } \\
\text { family }\end{array}$ & $\begin{array}{c}\text { Average } \\
\text { members / } \\
\text { family }\end{array}$ & $\begin{array}{c}\text { Average } \\
\text { members / } \\
\text { family }\end{array}$ \\
\hline District & 4.7 & 4.0 & 4.3 & 4.1 & 4.1 & -20.3 \\
\hline Gjirokast. & 4.4 & 4.0 & 4.3 & 4.0 & 4.0 & -12.3 \\
\hline Permet & 4.6 & 4.0 & 4.1 & 4.0 & 4.2 & -26.2 \\
\hline Tepelene & 4.9 & 4.0 & 4.3 & 4.3 & 3.9 & -27.2 \\
\hline
\end{tabular}

Changes in the dimension of the family in this district reflects the situation of this decline by towns and villages.

\section{THE RESULTS OF THIS ANALYSIS}

After 1989, the analysis of the structure of households by size notes:

- The process of "distribution" of large families, with over 6 family members constitutes $17.6 \%$ of the whole number of families in the region [4].

- This process which has the tendency of a trend appears not to be the same across all the districts. In Tepelena for instance the weight of very large families continues to be maintained, especially in the countryside where they occupy $26.7 \%$ of the total number of households (in the village). This shows that the tradition for a big family in this population is still strong.

- The number of small families with 1 - 2 family members has a $18.6 \%$ lower rate in comparison to the total number of families in the county.

- The largest number of very small families with 1to 2 people are those in Gjirokastra district due to the migration of a very large population to Greece.

- Families with two children constitute about $77.0 \%$ of the total number of families in the district of Gjirokastra. 
- In second place came families with children from 3 to 5 and finally those with over 6 children who make up less than $1.0 \%(0.7 \%)$ of the total number of families in the county.

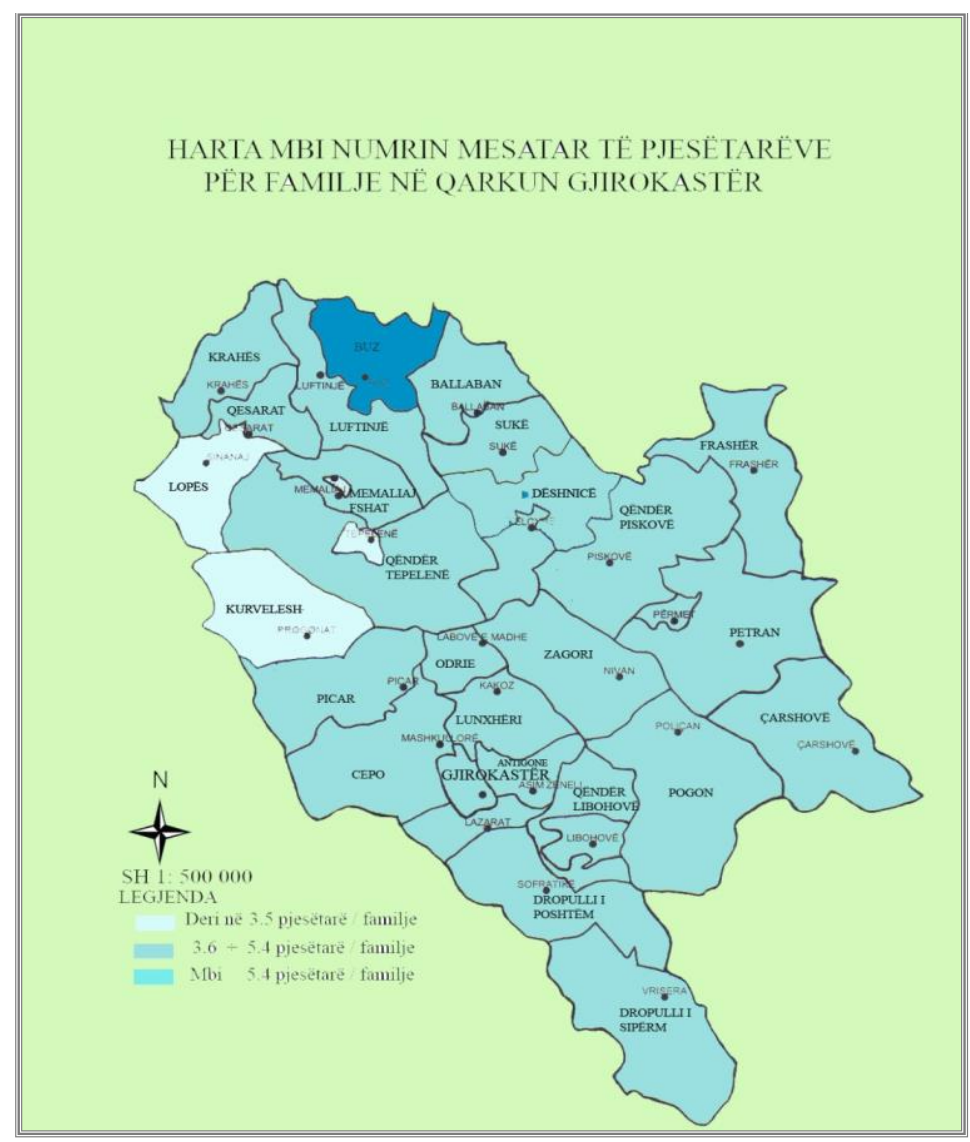

Figure Nr. 3. The map of average members / family [4] (The map is prepared by V.Duri)

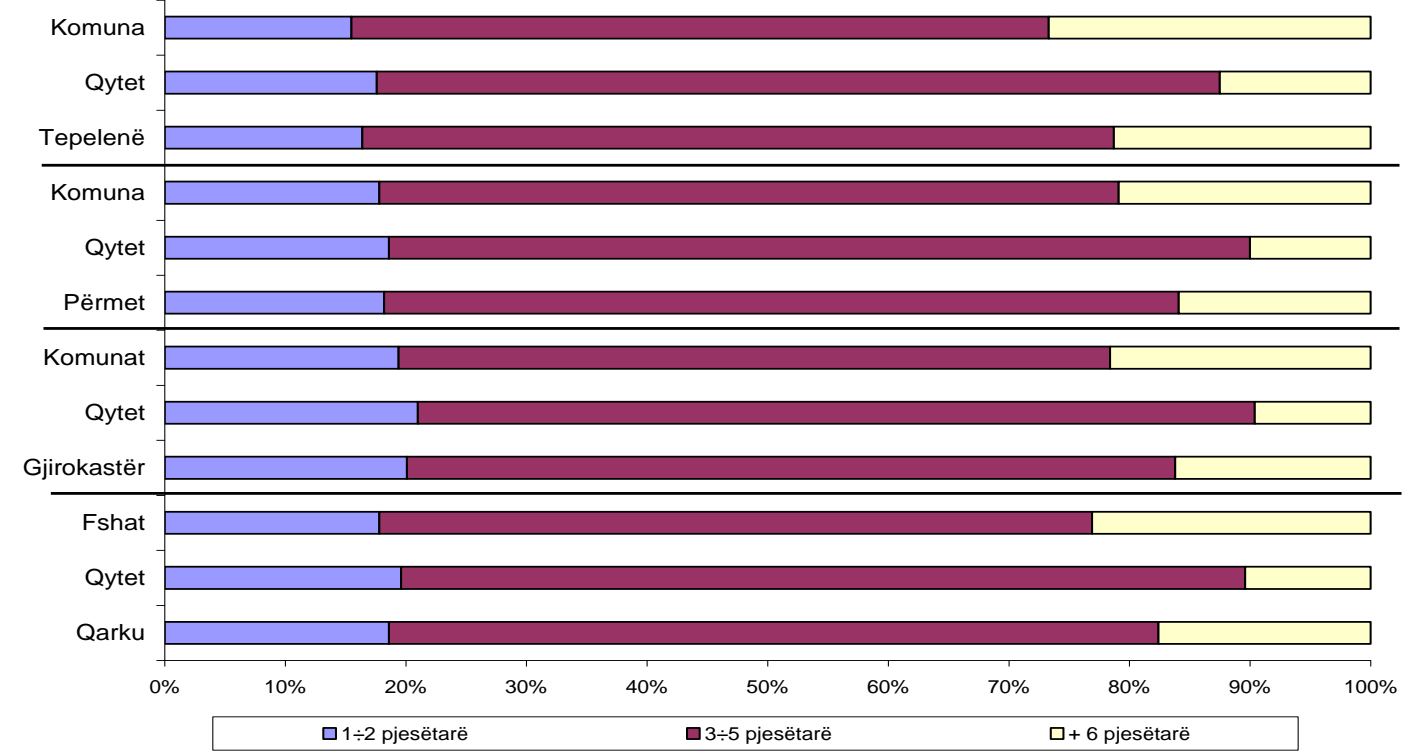

Figure Nr.4. Families according the number of the members in Gjirokastra region. [4] 
The disintegration of large families and their replacement with smaller families with up to 2 members relates to changes that occurred in Albania after the collapse of the socialist system and extensive road development (labor force growth by increasing the population).

Factors such as:

$\checkmark$ The transition from central planned socialist economy into a free market economy

$\checkmark$ economic crisis in the late 1980s,

$\checkmark$ increase in unemployment,

$\checkmark$ reduction of income,

$\checkmark$ private ownership, family planning, reduction in fertility by half

$\checkmark$ influx of population in cities,

$\checkmark$ abandonment of the villages

$\checkmark$ the continuation of the emigration

$\checkmark$ the ageing population,

$\checkmark$ the decay gender equilibrium (male emigration),

$\checkmark$ weakening of the traditional psychology,

$\checkmark$ Increased economic uncertainty, which are the main factors that brought significant change in the performance and features of the Albanian family. The number of marriages, divorces and civil structure of the population did not only occurred in the south of Albania.

\section{REFERENCES}

[1] INSTAT Republic of Albania Directorate of Statistics Gjirokaster, Permet, Tepelene (2001)

[2] INSTAT Republic of Albania Directorate of Statistics Gjirokaster, Permet, Tepelene 2001

[3] INSTAT Republic of Albania Directorate of Statistics Gjirokaster, Permet, Tepelene 1994, 1999, 2009.

[4] INSTAT Republic of Albania Directorate of Statistics Gjirokaster, Permet, Tepelene (2009).

[5] Vjetari statistikor i RPS të Shqipërisë 1989, Tiranë, 1990 